\title{
An international palaeo-environmental project at Paakitsoq, West Greenland
}

\author{
Henrik Højmark Thomsen, Pierre E. Biscaye, Jocelyne C. Bourgeois, \\ Carl Egede Bøggild, Hans Oerter, Niels Reeh and \\ Thorsteinn Thorsteinsson
}

Deep ice-core drilling programmes on the central part of the Greenland and Antarctic ice sheets have demonstrated that large ice sheets contain unique sources of information about climate and environment during the past c. 250000 years (Dansgaard et al., 1982, 1993; Lorius et al., 1985; Jouzel et al., 1987, 1993).

Oxygen isotope climate research carried out in ice margin regions in Greenland and Antarctica has revealed that the old ice found at depth in the central regions of the ice sheets can also be retrieved at the ice sheet margins, where ice of different ages is found in a sequence with the oldest ice nearest to the ice edge (Lorius \& Merlivat, 1977; Reeh et al., 1987, 1991). An international research project has been focused on the Inland Ice margin at Paakitsoq in West Greenland.

The easily accessible ice at Paakitsoq offers a favourable opportunity to study the major climatic events that occurred during the last glacial cycle, since large samples of ice with a limited age-range can be obtained. In this sense the ice margin record is an alternative to the deep ice-core records where the number of environmental parameters that can be studied is limited by the amount of ice available, each parameter requiring a certain amount of ice for its analysis (Reeh et al., 1993). This possibility has attracted the attention of scientists working with environmental parameters requiring large ice samples. A Danish, American, Canadian and German joint project was therefore initiated, and in April 1994 a programme of retrieving ice samples for studies of pollen, dust, chemistry, textures, fabric and visual stratigraphy was carried out. Furthermore, measurements of mass balance, ice velocity and deformation were made. In addition to the possibility of studying the variation of environmental parameters over a full glacial cycle, the project will also support the establishment of a better chronology along the Paakitsoq profile.

\section{The Paakitsoq ice margin area and climate record}

The Paakitsoq ice margin area lies $c .40 \mathrm{~km}$ north-east of the town of Ilulissat/Jakobshavn in West Greenland (Fig. 1). In 1985, 1988 and 1992 surface ice was sampled along a profile on the ice sheet margin (Fig. 1); the profile has now been sampled continuously at $20 \mathrm{~cm}$ intervals over $600 \mathrm{~m}$.
Analyses of the samples for $\delta^{18} \mathrm{O}$ shows that Pleistocene ice, which was originally deposited on the central part of the Greenland ice sheet, now outcrops in an approximately $600 \mathrm{~m}$ wide zone along the margin of the ice sheet.

Comparison of the $\delta^{18} \mathrm{O}$ record at Paakitsoq with deep ice-core records from Dye 3 and Camp Century, Greenland and the Vostok deep ice core record from Antarctica, allows an interpretation of the Paakitsoq record in terms of Emiliani isotopic stages (EIS) (Fig. 2) and a translation of the $\delta^{18} \mathrm{O}$ record into a Greenland temperature record covering the past c. 150000 years (Reeh et al., 1991). This includes the early part of the Holocene, Weichsel, Eem and also a part of the Saale.

The sampling profile at Paakitsoq is located at an elevation of $c .380 \mathrm{~m}$ in a cul-de-sac region of the ice margin, where ice motion is stagnant (Fig. 1). The surface is nearly horizontal with a mean slope of only $2^{\circ}$, but local surface irregularities with wave-lengths and wave-heights of typically $2-5 \mathrm{~m}$ and $0.5 \mathrm{~m}$ respectively are common features. The surface is furthermore characterised by a marked foliation approximately parallel with the ice margin, made up of alternating zones of dark and light coloured ice as well as blue bands and dirt bands. The light surface ice is generally coarser grained than the dark ice (Reeh et al., 1993). Cryoconite holes are more abundant in the light coloured ice than in the dark ice where the dirt particles seem to be more uniformly distributed at the surface. Comparison of the foliation banding and the oxygen isotope values of surface ice samples shows that light and dark coloured ice is associated with respectively relatively high and low $\delta^{18} \mathrm{O}$ values. Blue bands. $1-50 \mathrm{~cm}$ wide which can be followed over distances of several hundred metres are common features. They consist of clear coarse-grained ice with $\delta^{18} \mathrm{O}$ values several permille higher than the surrounding ice. No explanation of this $\delta^{18} \mathrm{O}$ anomaly is known, but judging from detailed sampling across the bands, they do not significantly interrupt the continuity of the $\delta^{18} \mathrm{O}$ record (Reeh et al., 1991). Dirt bands, consisting of small pocket-like inclusions of fine debris, are also common and seem to be located in zones; these can also be followed laterally over distances of several hundred metres. Both blue bands and dirt bands dip $70^{\circ} \mathrm{SE}$ along the whole profile. It is tempting to interpret these bands as inherent features parallel with 


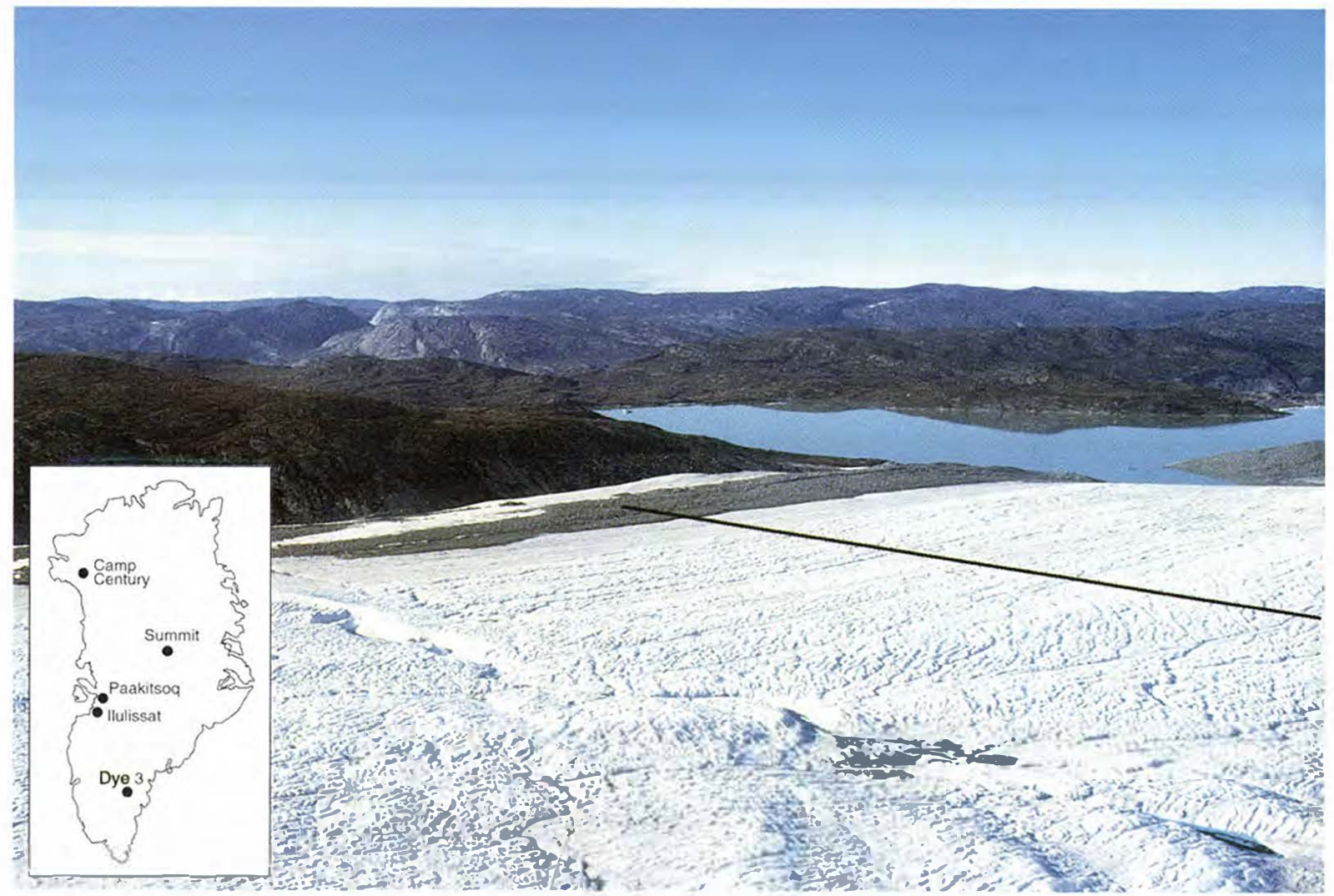

Fig. 1. The ice margin at Palakitsoy in West Greenland seen from the south-eatst showing the simpling profile on the ice. The marked linear foliation parallel with the ice margin is clearly seen: the irregular pattern on the ice surface is due to numerous small meltwatter streams. Insert map) shows location of Palakitsoy and the three deep ice core drilling sites. Dye 3. Camp Century and Summit (GRIP and (iISP2).

the bedding in the ice, but it is still an open question whether this is the case, or whether they represent a secondary phenomenon.

\section{Sampling of ice for dust studies}

Sampling of ice for dust studies was carried out by the Lamont-Doherty Earth Observatory of Columbia University, USA (LDEO) (Biscalye, 1994). The primary objective was to obtain samples of ice for atmospheric dust analysis. in order to determine transport pathways of different air masses traversing Greenland during the changing climatic conditions of the last $1(0)(0)(0)$ years. Provenance studies of atmospheric dust in ice cores from deep drill holes using mineralogical and $\mathrm{Sr}$ - and $\mathrm{Nd}$-isotope composition analyses have previously been carried out at LDEO. To develop and implement more refined analytical techniques larger samples of dust are needed, and the ice margin location at Palakitsog offers the opportunity to obtain samples larger than those obtained by conventional deep drilling.

Samples for dust analysis in ice from the Holocene to the previous glacial (Salale), were extracted from ice samples collected for pollen analysis (see below). Ice cores were also drilled along the profile, where the oxygen isotope record showed the existence of several abrupt climatic events. This covers the transition from the last glacial period to the Holocene, which includes ice from the Bolling. Allersd and Younger Dryas periods.
EIS

\section{6}

(n)

5

5

4

\begin{tabular}{|l|l|l}
\hline 3 & 2 & 1 \\
\hline
\end{tabular}

$\begin{array}{lrrrr}200 & 300 & 400 & 500 & 600 \\ \text { Distance from ice margin in metres } & & \end{array}$

[Fig. 2. Interpretation of the Palakitsog ice margin record in terms of Emiliant isotopic stages (EIS) plotted as a function of distance from the start of the profile at the ice margin. 
The dust samples will be analysed for mineralogical and $\mathrm{Sr}$ - and Nd-isotopic composition in order to identify or at least place boundary conditions on the provenance of the dust. The techniques used are similar to those used at LDEO on smaller samples from the GISP2 ice core drilled at Summit in the central part of the Greenland ice sheet, and on samples from the last glacial maximum in East Antarctica (Grousset et al., 1992).

\section{Sampling for pollen}

Sampling of ice for pollen studies was carried out by the Geological Survey of Canada (GSC) (Bourgeois, 1994). The main objective of this pollen study was to analyse samples along the profile, at major changes in the isotopic record, to determine whether these fluctuations also correspond to changes in the pollen record. Pollen fluctuations in the ice may reflect changes of vegetation or, perhaps, reflect changes in atmospheric circulation over the ice sheet. Both possibilities will have to be considered in the interpretation of the data.

Studies of pollen in polar ice caps require large volumes of ice due to the low concentration of pollen. Ice in such large quantities is normally not available through conventional ice core drilling, unless several core segments are combined; it is sometimes possible for ice from the Holocene period, where the ice is less compressed and therefore has a higher resolution. However, there is a risk in combining a large time increment in Pleistocene ice thereby obliterating some climatic signals. One way to overcome this problem is by melting a large volume of ice in situ at selected levels in deep boreholes and pumping the water to the surface. This method was first tried in two $c$. $130 \mathrm{~m}$ deep boreholes on the Agassiz Ice Cap in the Canadian Arctic (Koerner et al., 1988; Bourgeois, unpublished results). This study showed the bottom ice to be of interglacial origin. However, other pollen fluctuations seen in the Ice Age and Late Glacial were more difficult to interpret because of a lack of chronological control, mainly due to the small amount of Pleistocene ice available at the bottom of the ice cap.

Compared to deep boreholes, the ice margin location at Paakitsoq offers a nearly $600 \mathrm{~m}$ long profile of old ice, where samples with large volumes can be easily collected. Samples with a volume of approximately 40 litres were melted in situ, using an immersion heater installed in core holes drilled to one metre depth, and filtered on location for pollen.

\section{Ice sampling for ${ }^{10} \mathrm{Be}$}

One of the major problems for interpretation of climatic and environmental records from ice sheets is the establish- ment of reliable time scales (Budd et al., 1989; Hammer, 1989; Reeh, 1989). Well established, absolute dating methods are only valid for dating a few tens of thousands of years back in time (Hammer, 1989). For older ice, one is dependent on ages calculated from ice-flow models which are based on assumptions about climate history and ice temperature (e.g. Lorius et al., 1985). These calculations are less reliable the further back in time the dating is extended. However, different records can be correlated by matching well-defined stratigraphic features and marked patterns in the recorded parameters.

The Paakitsoq ice margin record has been correlated with the Greenland deep drilling records from Dye 3 and Camp Century, and the Vostok deep ice-core from Antarctica. The correlation is based on marked events in the $\delta^{18} \mathrm{O}$ record and a time scale established using ${ }^{10} \mathrm{Be}$ peaks in the Camp Century and Vostok cores as time markers (Reeh et al., 1991). Raisbeck et al. (1987) concluded that the two distinct peaks at c. $35 \mathrm{ka}$ and $60 \mathrm{ka}$ in the Vostok ${ }^{10} \mathrm{Be}$ record are most likely due to production-rate changes in the atmosphere caused by extraterrestrial disturbances, and should therefore also be detectable in Greenland ${ }^{10} \mathrm{Be}$ records; two distinct ${ }^{10} \mathrm{Be}$ peaks are in fact found in the Camp Century ${ }^{10} \mathrm{Be}$ record (Reeh et al., 1991). However, Beer et al. (1992) questioned the existence of the $60 \mathrm{ka}$ ${ }^{10} \mathrm{Be}$ peak in the Camp Century record, as only the $35 \mathrm{ka}$ peak was found in their study.

To obtain further time markers in the Paakitsoq ice margin record, sampling of ice for ${ }^{10} \mathrm{Be}$ analysis was made by the Danish Polar Center and the Geological Survey of Greenland (Reeh \& Thomsen, 1994). The sampling was concentrated on locating the possible ${ }^{10} \mathrm{Be}$ peak at $35 \mathrm{ka}$ which has been found in the Camp Century record from North Greenland. A total of 51 samples each with a volume larger than one litre were drilled symmetrically around the expected location of the $35 \mathrm{ka}$ peak with a sample spacing of $2.5 \mathrm{~m}$.

\section{Studies of texture, fabric and visual stratigraphy}

Ice crystals in polar ice sheets constantly undergo growth, rotation and recrystallisation to accommodate changing stress systems, strain and temperature. Thin section studies on existing deep ice cores from the central part of the Greenland ice sheet, drilled at Camp Century, Dye 3 and Summit (GRIP and GISP2 deep drill sites; Fig. 1) have revealed that: (1) grain growth occurs in the uppermost $600-700 \mathrm{~m}$ of the ice sheet but below that is inhibited by increasing strain of the ice and the presence of impurities; (2) $c$ axes rotate towards the vertical axis of compression and thus a pattern of preferred orientation is found in the lower part of the ice sheet (Herron et al., 1985); (3) crystal- 
size variations observed in the GRIP core are found to be strongly correlated with variations in climatic parameters, such as $\delta^{18} \mathrm{O}$ and dust; (4) dynamic recrystallisation leading to the growth of large crystals appears to occur in the lowest central part of the Greenland ice sheet.

Ice cores have not previously been retrieved from the ice margin regions, and no information is therefore available on ice crystal development during flow from the inner regions of the ice sheet to the margin. In order to gain information about changes in ice crystals during flow through the ice sheet and about the complex ice flow situation near the ice margin, a total of 81 cores with lengths of $0.4-1.2 \mathrm{~m}$ were retrieved by the Alfred Wegener Institute, Germany, from 71 different locations along the entire profile (Thorsteinsson \& Oerter, 1994).

The crystal-size variation in the GRIP ice core shows a dependence on climatic conditions, as small crystals are present in Weichselian and Saalean ice and large crystals in Eemian ice, with a strong correlation between crystal size and the measured $\delta^{18} \mathrm{O}$ values of the ice. The Paakitsoq ice will be studied for similar relationships and, if found, they will constitute important support for the Paakitsoq climatic record. In addition, this would show that the original texture from the inner ice sheet regions is inherited at the ice margin in spite of recrystallisation due to ice flow.

\section{Measurements of ice deformation and velocities}

To help interpret the environmental record obtained from the ice margin profile, studies of surface topography, mass balance and ice dynamics were initiated in 1988 by the Alfred Wegener Institute, Germany and continued in 1992 by the Danish Polar Center and the Geological Survey of Greenland (Reeh et al., 1994). During the 1994 field work a network of 10 previously established stakes around the sampling line were remeasured for determination of ablation, surface elevation, ice velocity and strain rate.

The measurements show that the ice velocity decreases from about $17 \mathrm{~m} / \mathrm{yr}$ one kilometre inland to about $2 \mathrm{~m} / \mathrm{yr}$ a few metres from the ice margin. The strain-rate distribution along the profile shows the principal compressive and tensile stresses to be directed approximately along and transverse to the profile line. Furthermore, it was shown that the strike of the marked surface foliation does not change significantly from one year to another.

Measurements of the vertical ice motion show that the dip of the velocity vector increases towards the ice margin and northwards from the profile line. The ice motion measurements also show that the inclination of the velocity vector $\left(10^{\circ}-40^{\circ}\right)$ is much smaller than the inclination of the observed blue bands and dirt bands $\left(70^{\circ}\right)$. For steady state flow the ice bedding tends to be aligned with the direction of motion near the margin (Paterson, 1981, p. 222). However, a comparison of distinct features in the $\delta^{18} \mathrm{O}$ profiles obtained along the profile line in 1988 and 1992 indicates that flow conditions at the profile site are far from steady state, and thus bedding and ice motion need not be parallel.

\section{Future work}

A possible continuation of the fieldwork at Paakitsoq awaits the results of laboratory work at the involved institutions. However, detailed studies of the flow conditions at the profile and the implications for the bedding are in progress.

\section{References}

Beer, J., Johnsen, S. J., Bonani, G., Finkel, R. C., Langway, C. C., Oeschger, H., Stauffer, B., Suter, M. \& Woelfli, W. 1992: ${ }^{10} \mathrm{Be}$ peaks as time markers in polar ice cores. In Bard, E. \& Broecker, W. S. (ed.) The last deglaciation: absolute and radiocarbon chronologies, 141-153. Berlin: Springer-Verlag.

Biscaye, P. E. 1994: Sampling of ice for dust studies on the ice margin at Paakitsoq, West Greenland. In Thomsen, H. H. \& Reeh, N. (ed.) Field report on palaeo-environmental studies at the Greenland ice sheet margin, Paakitsoq, West Greenland, 1994. Open File Ser. Grønlands geol. Unders. 94/15, $10-15$.

Bourgeois, J. E. 1994: Sampling for pollen on the ice margin at Paakitsoq, West Greenland. In Thomsen, H. H. \& Reeh, N. (ed.) Field report on palaeo-environmental studies at the Greenland ice sheet margin, Paakitsoq, West Greenland, 1994. Open File Ser. Grønlands geol. Unders. 94/15, 16-19.

Budd, W. F., Andrews, J. T., Finkel, R. C., Fireman, E. L., Graf, W., Hammer, C. U., Jouzel, J., Raynaud, D. P., Reeh, N., Shoji, H., Stauffer, B. R. \& Weertman, J. 1989: How can ice chronology be established? Group report. In Oeschger, H. \& Langway, C. C. Jr (ed.) The environmental record in glaciers and ice sheets, 177-192. New York: Wiley.

Dansgaard, W., Clausen, H. B., Gundestrup, H., Hammer, C. U., Johnsen, S. J., Kristinsdóttir, P. M. \& Reeh, N. 1982: A new Greenland deep ice core. Science 218, 1273-1277.

Dansgaard, W., Johnsen, S. J., Clausen, H. B., Dahl-Jensen, D., Gundestrup, N. S., Hammer, C. U., Hvidberg, C. S., Steffensen, J. P., Sveinbjörnsdóttir, A. E., Jouzel, J. \& Bond, G. 1993: Evidence for general instability of past climate from a 250 kyr ice-core record. Nature 364, 218-220.

Grousset, F. E., Biscaye, P. E., Revel, M. Petit, J. R., Pye, K., Joussaume, S. \& Jouzel, J. 1992: Antarctic (Dome C) ice core dust at 18 k.y. B.P.: isotopic constraints on origins. Earth Planet. Sci. Lett. 111, 175-182.

Hammer, C. U. 1989: Dating by physical and chemical seasonal variations and reference horizons. In Oeschger, H. \& Langway, C. C. Jr (ed.) The environmental record in glaciers and ice sheets, 99-121. New York: Wiley.

Herron, S. L., Langway, C. C. \& Brugger, K. A. 1985: Ultrasonic velocities and crystalline anisotropy in the ice core from Dye 3, Greenland. In Langway, C. C., Oeschger, H. \& Dansgaard, 
W. (ed.) Greenland ice core: geophysics, geochemistry and the environment. Geophysical Monograph, Am. Geophysical Union 33, 23-31.

Jouzel, J., Lorius, C., Petit, J. R., Barkov, N. I., Kotlyakov, V. M. \& Petrov, V. M. 1987: Vostok ice core. A continuous isotopic temperature record over the last climatic cycle (160,000 years). Nature 329, 403-408.

Jouzel, J., Barkov, N. I., Barnola, J. M., Bender, M., Chappellaz, J., Genthon, C., Kotlyakov, V. M., Lipenkov, V., Lorius, C., Petit, J. R., Raynaud, D., Raisbeck, G., Ritz, C., Sowers, T., Stievenard, M., Yiou, F. \& Yiou, P. 1993: Extending the Vostok ice-core record of palaeoclimate to the penultimate glacial period. Nature 364, 407-412.

Koerner, R. M., Bourgeois, J. C. \& Fisher, D. A. 1988: Pollen analysis and discussion of time-scales in Canadian ice cores. Ann. Glaciol. 10, 85-91.

Lorius, C. \& Merlivat, L. 1977: Distribution of mean surface stable isotope values in East Antarctica. Observed changes with depth in the coastal area. Publ. Assoc. int. hydrol. Scient. 118, 127-137.

Lorius, C., Jouzel, J., Ritz, C., Merlivat, L., Barkov, N. I., Korotkevich, Y. S. \& Kotlyakov, V. M. 1985: A 150,000-year climatic record from Antarctica ice. Nature 316, 591-596.

Paterson, W. S. B. 1981: The physics of glaciers. 2nd edit. Oxford: Pergamon Press.

Raisbeck, G. M., Yiou, F., Bourles, D., Lorius, C., Jouzel, J. \& Barkov, N. I. 1987: Evidence for two intervals of enhanced ${ }^{10} \mathrm{Be}$ deposition in Antarctic ice during the last glacial period. Nature 326, 273-277.

Reeh, N. 1989: Dynamic and climatic history of the Greenland ice sheet. In Fulton, R. J.(ed.) Quaternary geology of Canada and Greenland. Geology of Canada 1, 795-821. Ottawa: Geological Survey of Canada.

Reeh, N. \& Thomsen, H. H. 1994: Ice sampling for ${ }^{10} \mathrm{Be}$ and $\delta^{18} \mathrm{O}$ analysis on the ice margin at Paakitsoq, West Greenland. In Thomsen, H. H. \& Reeh, N. (ed.) Field report on palaeoenvironmental studies at the Greenland ice sheet margin, Paakitsoq, West Greenland, 1994. Open File Ser. Grønlands geol. Unders. 94/15, 30-34.
Reeh, N., Thomsen, H. H. \& Clausen, H. B. 1987: The Greenland ice-sheet margin - a mine of ice for paleo-environmental studies. Palaeogeogr. Palaeoclimat. Palaeoecol. (Global planet. Change Sect.) 58, 229-234.

Reeh, N., Oerter, H. \& Miller, H. 1993: Correlation of Greenland ice-core and ice-margin $\delta\left({ }^{18} \mathrm{O}\right)$ records. In Peltier, W. R. (ed.) Ice in the climate system. NATOAdv. Sci.Inst. Ser. I, 12, 481-497. Berlin: Springer-Verlag.

Reeh, N., Thomsen, H. H., Oerter, H. \& Bøggild, C. E. 1994: Ice deformation and velocities along the Paakitsoq profile sampling line, West Greenland. In Thomsen, H. H. \& Reeh, N. (ed.) Field report on palaeo-environmental studies at the Greenland ice sheet margin, Paakitsoq, West Greenland, 1994. Open File Ser. Grønlands geol. Unders. 94/15, 20-29.

Reeh, N., Oerter, H., Letréguilly, A., Miller, H. \& Hubberten, H. W. 1991: A new, detailed ice-age oxygen-18 record from the ice-sheet margin in central West Greenland. Palaeogeogr. Palaeoclimat. Palaeoecol. (Global planet. Change Sect.) 90, 373-383.

Thorsteinsson, T. \& Oerter, H. 1994: Ice core drilling for studies of texture, fabric and visual stratigraphy on the ice margin at Paakitsoq, West Greenland. In Thomsen, H. H. \& Reeh, N. (ed.) Field report on palaeo-environmental studies at the Greenland ice sheet margin, Paakitsoq, West Greenland, 1994. Open File Ser. Grønlands geol. Unders. 94/15, 35-40.

H. H. T. \& C. E. B., Geological Survey of Denmark and Greenland, Copenhagen

P. E. B., Lamont-Doherty Earth Observatory of Columbia University, Palisades NY 10964, USA

J. C. B., Geological Survey of Canada, 601 Booth St., Ottawa, Canada K1A OE8

H. O. \& T. T., Alfred Wegener Institute for Polar and Marine Research, Postfach 120161, Columbusstrasse, D-27515 Bremerhaven, Germany

N. R., Danish Polar Center, Strandgade 100 H, DK-140I Copenhagen $K$, Denmark 